\title{
Developmental biology of Aspavia armigera (FABRICIUS, 1775) (Hemiptera: Pentatomidae) on rice (Oryza sativa L.) (Poaceae) and three other hosts in Nigeria
}

\author{
Abiodun Oladipupo JODA* \\ Department of Crop Production, Olabisi Onabanjo University, Ago-Iwoye, Nigeria
}

\begin{abstract}
The developmental biology of Aspavia armigera on four rice varieties ITA 301, ITA 305, ITA 307 and ITA 315 was studied under ambient conditions at the Plant Biology Laboratory, Olabisi Onabanjo University, Ago-Iwoye, Nigeria. Alternative host plants were also used in the experiment. The results showed that the development of A. armigera depended on its hosts. Oviposition periods were 41.7 days, 30.8 days, 22.6 days and 18.1 days on rice varieties ITA 301, ITA 305, ITA 307 and ITA 315, respectively. Fecundity ranged from 80.3 eggs on ITA 301, 79.6 eggs on ITA $307,76.1$ eggs on ITA 305 and 65.6 eggs on ITA 315 . The differences in fecundity were not statistically significant. The eggs incubated for 4 to 6 days before hatching into nymphs on all the varieties. The longevity of mated and unmated males and mated females on the rice varieties were not statistically different, while unmated females lived significantly longer on ITA 305 . There were five nymphal instars, which persisted for 16.8-19.5 days depending on the variety. The developmental period was significantly $(\mathrm{p}<0.05)$ delayed on ITA 315 , and the mean growth ratio of head capsule measurements was 1.27. Oviposition periods ranged between 5 and 20 days on cowpea and 6 and 18 days on rice. A significantly higher number of eggs (fecundity) was laid by mated females of A. armigera fed on soybean than those fed on cowpea. Mean developmental periods were $25.7,25.5,21.4$, and 20.3 days on soybean, amaranthus, rice and cowpea, respectively. Mated females lived for a significantly shorter period on cowpea (21.9 days) than on the other hosts.
\end{abstract}

KEY WORDS: host plant, oviposition, longevity, amaranthus, life cycle

*Corresponding author: abijod@gmail.com 


\section{INTRODUCTION}

Alydid and pentatomid bugs are mainly seed pests of rice worldwide (LITSINGER et al. 1986, FOSTER et al. 1989). The pentatomids are commonly referred to as shield bugs, among which are Aspavia STÅL, 1865 species and Nezara viridula (LINNAEUS, 1758). At least three different species of Aspavia exist on rice, the most abundant being A. armigera (FABRICIUS, 1775) and to a lesser extent A. acuminata MonTANDON, 1894. Adults and nymphs generally feed on the developing seeds and sometimes on the stem (IITA 1984). The colour of the adult Aspavia is brown with three yellow spots at the apices of the triangular scutellum. The dorsal surface of the prothoracic plate has a pointed projection (spine) on each side. The adult of A. armigera is about 8-9 $\mathrm{mm}$ long and 4-5 $\mathrm{mm}$ wide. The yellow spots are smaller than the bolder ones of A. acuminata. The size of the yellow spots generally differentiates one species of Aspavia from another (UMEH 1991). Aspavia is found in Africa (though not in all parts) in three climatic zones.

Only three species occur in East Africa and there are two more in West African countries (ALAM et al. 1983, JOHN et al. 1986). Aspavia infestation is very important in the production of rice and other grains. The feeding of both the adult and nymphs of Aspavia species, especially A. armigera at the dough stage, results in partially filled grains of low quality. Unprocessed panicles (paddy) usually have diffuse brown spots indicating areas of attack on the grains by the bugs. However, infested grains turn dirty brown to black during parboiling, thus affecting their aesthetic value. Therefore, attack on panicles at the milk and dough stages may be viewed as affecting the quality of the grains rather than yield loss (UMEH et al. 1991, BURDEOS \& GABRIEL 1995).

On cowpea (Vigna unguiculata L. WALP.), Aspavia armigera caused a significant yield loss at 2 bugs per 10 plants and a total seed loss as a population of 16 bugs per 10 plants (PITAN et al. 2007). Aspavia species continue to be more important economically to rice production in Nigeria. Despite the importance of the pests in the production of rice and other crops, little information is available on the pest, especially its developmental biology on rice. This information is necessary during the planning stage of control programmes. Hence, the objective of the study was to elucidate the developmental biology of $A$. armigera on rice and other hosts.

\section{MATERIALS AND METHODS}

\section{Experiment 1: Biology of Aspavia armigera on four rice varieties}

Four rice varieties (ITA 301, ITA 305, ITA 307 and ITA 315), supplied by Africa Rice Ibadan, were sown in pots at the Plant Biology Laboratory, Olabisi Onabanjo University, 
Ago-Iwoye. Four pots $(20 \mathrm{~cm}$ diameter) were filled with sieved top soil and seeded with each rice variety. Six seeds were dibbled per pot and after germination were thinned down to two seedlings. The pots were watered twice daily during the dry season, once every other day during the rainy season and as necessary. The potted rice plants were allowed to develop until panicle formation. Fresh soft panicles of these rice varieties were obtained from the plants as foods for the insects.

\section{Insect culture and rearing cages}

Adults of Aspavia were collected from rice fields around Ago-Iwoye, Ogun State, Nigeria, and the sexes of the insects were determined by comparing their external genitalia. A pair, male and female, was enclosed in each of ten plastic cages of dimensions (14 x 9 x $6 \mathrm{~cm}$ ) with a lid. They were supplied with fresh panicles of ITA 301, ITA 305, ITA 307 and ITA 315 every other day. These soft panicle stalks were inserted into moistened cotton wool already plugged into a glass vial in the cages to preserve their freshness and to provide water for the insect. A. armigera adults were left in the cages to oviposit. Fresh eggs were collected from these cages every morning and placed in plastic Petri dishes, each with a lid and lined with moistened Whatman No. 9 filter paper. The Petri dishes were labelled to indicate the date of egg collection and hatching as well as the rice variety from which eggs were collected. Eggs were incubated at ambient laboratory temperature 24$27^{\circ} \mathrm{C}$ and relative humidity $88-92 \%$. The neonate nymphs used in the subsequent experiments were obtained from the culture.

Observations on egg viability, nymphal development, growth index, sex ratio and longevity of $A$. armigera on four rice varieties

Sixty nymphs of A. armigera that hatched from the incubated eggs were reared singly in separate cages on each of the four rice varieties. The developmental periods of each nymphal instar was monitored daily by looking for exuviae, a clear indication of moulting (EWETE \& OlaGBAJU 1990). Fresh soft panicles and water were supplied every day and the cages kept clean by removing the secretions and faeces inside them. Dead nymphs were replaced with newly hatched ones. The developmental period (nymph-adult) was recorded. Observations were made on nymphal survival at each stage and the sex ratio. The growth index was determined using CATINDIG et al. (1993):

$$
\text { Growth index }=\frac{\text { Larval survival (\%) }}{\text { Larval growth period (days) }}
$$

Adults that emerged from this study were paired immediately to study the lifespan of mated A. armigera. Similarly, the longevity of 10 unmated males and females of $A$. armigera on each rice variety was studied. 
Observations of pre-mating, mating, pre-oviposition, oviposition periods, egg viability and fecundity of Aspavia armigera

A pair of teneral adults ( 1 male +1 female) removed from the insect culture was placed in each of the 15 plastic cages described earlier. They were supplied with soft panicles of each of the four rice varieties (ITA 301, ITA 305, ITA 307 and ITA 315), which served as treatments in a completely randomized design. Each treatment was applied 15 times. Observations were made on pre-mating, mating, pre-oviposition, oviposition periods and fecundity of the mated females in each of the plastic cages on each rice variety. Dead insects were replaced with teneral adults of the appropriate sex (to ensure continuous mating). The eggs collected from the cages were allowed to incubate in separate Petri dishes and their viability was recorded. Similar experimental procedures were carried out and observations made on 10 unmated females on each rice variety.

\section{Morphometrics of the developmental stages of Aspavia armigera}

Thirty eggs sampled from the A. armigera egg batches and twenty nymphs from each of the developmental stages were killed with ethyl acetate one day prior to the next moulting and preserved in $70 \%$ ethanol for 24 hours. Similarly, ten male and female adults were killed in the same way as the nymphs and their body length, width of abdomen and head capsule (vertex) measured. All measurements were made under a drawing microscope (x 160) fitted with a graticule in its eye piece. Each immature stage was described.

Experiment 2: Biology of Aspavia armigera on its alternative hosts: soybean, cowpea, amaranthus

The same procedures for Experiment 1 on rice were followed except that different food sources were provided: soybean (TGX 1448-2E), cowpea (IT 86D-71\%), amaranthus (NH84/493), and rice (ITA 315) as control. Tender pods of soybean (R-5 stage), cowpea, soft panicles of rice and flower heads of amaranthus were supplied to nymphs of $A$. armigera in separate cages. The same observations of the developmental biology of $A$. armigera as in Experiment I were made and recorded.

\section{RESULTS}

\section{Experiment 1: Biology of Aspavia armigera on four rice varieties}

Egg viability, nymphal development, growth index, sex ratio and longevity of Aspavia armigera on rice varieties

Nymphs of A. armigera were successfully reared to adults on the four rice varieties. The first neonate nymphs appeared not to feed and had average developmental periods ranging 
from 2.3 days on ITA 301 to 3.0 days on ITA 315 . The fifth instar had the longest developmental period on the four varieties. However, the fourth and the fifth instar stages took a significantly longer period to develop on ITA 315 relative to the other varieties. The mean total nymphal developmental period was significantly shorter on ITA 301 (16.8 days) and longer (significantly delayed) on ITA 315 (19.5 days) than on the other varieties (Table $1)$. The highest percentage of viable eggs $(92 \%)$ was recorded when mated females were fed on rice variety ITA 301, while the lowest (85\%) was recorded on ITA 315 . The highest percentage nymphal survival (96\%) was recorded on ITA 305 and ITA 307, and 94\% on ITA 302 , which were statistically superior to the $86 \%$ recorded on ITA 315 (Table 2). Unmated males lived significantly longer on ITA 315, while unmated females lived longer on ITA 305 compared to the other varieties, which were not statistically different from one another. However, the longevities of the mated males and females did not vary significantly $(\mathrm{p}<0.05)$ among the four rice varieties tested (Table 3$)$.

Table 1. Mean duration (days \pm S.E) of Aspavia armigera nymphal development on four rice varieties.

\begin{tabular}{|c|c|c|c|c|}
\hline \multirow[t]{2}{*}{ Developmental period } & \multicolumn{4}{|c|}{ Rice variety } \\
\hline & ITA 301 & ITA 305 & ITA 307 & ITA 315 \\
\hline Instar I & $\begin{array}{c}2.8 \pm 0.29 \mathrm{a} \\
(2-5)\end{array}$ & $\begin{array}{c}2.6 \pm 0.22 \mathrm{a} \\
(2-4)\end{array}$ & $\begin{array}{c}2.3 \pm 0.15 \mathrm{a} \\
(2-3)\end{array}$ & $\begin{array}{c}3.0 \pm 0 \mathrm{a} \\
\text { (3) }\end{array}$ \\
\hline Instar II & $\begin{array}{c}2.8 \pm 0.13 \mathrm{a} \\
(2-3)\end{array}$ & $\begin{array}{c}3.4 \pm 0.27 \mathrm{a} \\
(2-5)\end{array}$ & $\begin{array}{c}3.1 \pm 0.18 \mathrm{a} \\
(2-4)\end{array}$ & $\begin{array}{c}3.8 \pm 0.13 a \\
(3-4)\end{array}$ \\
\hline Instar III & $\begin{array}{c}3.1 \pm 0.18 \mathrm{a} \\
(3-4)\end{array}$ & $\begin{array}{c}2.8 \pm 0.13 a \\
(2-3)\end{array}$ & $\begin{array}{c}3.1 \pm 0.18 \mathrm{a} \\
(2-4)\end{array}$ & $\begin{array}{c}3.2 \pm 0.13 \mathrm{a} \\
(3-4)\end{array}$ \\
\hline Instar IV & $\begin{array}{c}3.4 \pm 0.16 \mathrm{a} \\
(3-4)\end{array}$ & $\begin{array}{c}3.4 \pm 0.38 \mathrm{a} \\
(2-6)\end{array}$ & $\begin{array}{c}3.2 \pm 0.13 a \\
\quad(5-6)\end{array}$ & $\begin{array}{c}6.0 \pm 0.26 \mathrm{~b} \\
(5-6)\end{array}$ \\
\hline Instar V & $\begin{array}{c}5.0 \pm 0.21 \mathrm{a} \\
(4-6)\end{array}$ & $\begin{array}{c}5.2 \pm 0.21 \mathrm{a} \\
(4-6)\end{array}$ & $\begin{array}{c}5.2 \pm 0.13 a \\
(5-6)\end{array}$ & $\begin{array}{c}6.0 \pm 0.26 \mathrm{~b} \\
(5-6)\end{array}$ \\
\hline Mean developmental period & $\begin{array}{c}17.1 \pm 0.21 \mathrm{a} \\
(16-19)\end{array}$ & $\begin{array}{c}17.40 \pm 0.13 a \\
(16-19)\end{array}$ & $\begin{array}{c}16.8 \pm 0.13 a \\
(16-17)\end{array}$ & $\begin{array}{c}19.5 \pm 0.17 \mathrm{~b} \\
(18-21)\end{array}$ \\
\hline
\end{tabular}

$\mathrm{C} . \mathrm{V}=3.5 \% ; \mathrm{S} . \mathrm{E}=0.2$.

Means followed by the same letter in a row are not significantly different at the $5 \%$ level using DMRT.

The numbers in parentheses indicate the range.

\section{Pre-mating, mating, pre-oviposition, oviposition periods, egg viability and fecundity of} Aspavia armigera

A. armigera pre-mating, mating, pre-oviposition and oviposition periods were significantly longer on ITA 315 compared to the other varieties, which were statistically similar (Table 4). Copulation between adults of A. armigera was usually initiated by the 
Table 2. Egg viability, mean survival, growth index and sex ratio of Aspavia armigera reared on four rice varieties.

\begin{tabular}{lcccc}
\hline \multicolumn{1}{c}{ Parameter } & \multicolumn{4}{c}{ Rice variety } \\
\cline { 2 - 5 } & ITA 301 & ITA 305 & ITA 307 & ITA 315 \\
\hline Egg viability (\%) & 92 & 89 & 90 & 85 \\
\hline Instar I, survival (\%) & 90 & 80 & 80 & 100 \\
\hline Instar II , survival (\%) & 80 & 100 & 100 & 100 \\
\hline Instar III, survival (\%) & 100 & 100 & 100 & 100 \\
\hline Instar IV, survival (\%) & 100 & 100 & 100 & 100 \\
\hline Instar V, survival (\%) & 100 & 100 & 100 & $86.0 \mathrm{~b}$ \\
\hline Mean survival \% & $94.0 \mathrm{a}$ & $96.0 \mathrm{a}$ & $96.0 \mathrm{a}$ & 1.54 \\
\hline Growth index* & 4.09 & 4.6 & 3.6 & $1: 1.2$ \\
\hline Sex ratio (m:f) & $1: 1.1$ & $1: 1.4$ & $1: 1.1$ & 0 \\
\hline Means followed by & & & & \\
\hline
\end{tabular}

Means followed by the same letter in a row are not significantly different at the 5\% level using DMRT. Average sex ratio $=1: 1.2$.

Table 3. Mean longevity (days \pm S.E.) of unmated and mated adult Aspavia armigera reared on rice varieties.

\begin{tabular}{lcccc}
\hline \multirow{2}{*}{ Rice variety } & \multicolumn{4}{c}{ Male longevity \{days) } \\
\cline { 2 - 5 } & Unmated & Mated & Unmated & Mated \\
\cline { 2 - 5 } & $32.8 \pm 4.5 \mathrm{a}$ & $30.1 \pm 3.5 \mathrm{a}$ & $36.5 \pm 3.0 \mathrm{~b}$ & $46.1 \pm 5.1 \mathrm{a}$ \\
& $(9-45)$ & $(14-35)$ & $(23-55)$ & $(19-71)$ \\
\hline ITA 301 & $30.8 \pm 4.7 \mathrm{a}$ & $34.4 \pm 4.3 \mathrm{a}$ & $56.3 \pm 5.1 \mathrm{a}$ & $36.0 \pm 3.0 \mathrm{a}$ \\
& $(11-57)$ & $(10-52)$ & $(23-72)$ & $(17-49)$ \\
\hline ITA 305 & $43.0 \pm 4.9 \mathrm{a}$ & $29.0 \pm 4.1 \mathrm{a}$ & $44.7 \pm 3.0 \mathrm{~b}$ & $42.0 \pm 3.1 \mathrm{a}$ \\
& $(18-63)$ & $(9-50)$ & $(26-59)$ & $(26-53)$ \\
\hline ITA 307 & $51.5 \pm 6.9 \mathrm{~b}$ & $31.7 \pm 4.7 \mathrm{a}$ & $38.2 \pm 3.8 \mathrm{~b}$ & $33.1 \pm 4.4 \mathrm{a}$ \\
& $(10-67)$ & $(7-56)$ & $(9-54)$ & $(14-51)$ \\
\hline S.E. 315 & 4.9 & 4.4 & 4.2 & 3.8 \\
\hline C.V.\% & 36.2 & 44.1 & 30.1 & 30.1 \\
\hline M.an & & &
\end{tabular}

Means followed by same the letter in a row are not significantly different at the 5\% level using DMRT.

The numbers in parentheses indicate the range.

male stroking the female genitalia with its antennae. This stimulated the female. The male then turned around and introduced its genital organ (aedeagus) into the female genital opening. They positioned themselves with the tips of their abdomens adhering. Mating was frequent during the early mornings (06:00 to 10:00 hrs) and evening (16:30 to 19:00 hrs) and lasted for three hours. 
Table 4. Premating, pre-oviposition, oviposition periods and egg incubation periods (days \pm S.E) and fecundity of Aspavia armigera on four rice varieties.

\begin{tabular}{lcccc}
\hline \multirow{2}{*}{ Period (days) } & \multicolumn{4}{c}{ Rice variety } \\
\cline { 2 - 5 } & ITA 301 & ITA 305 & ITA 307 & ITA 315 \\
\hline Pre-mating & $5.5 \pm 0.4(3-7) \mathrm{a}$ & $6.9 \pm 0.5(5-9) \mathrm{a}$ & $9.6 \pm 1.1(6-15) \mathrm{b}$ & $18.2 \pm 0.7(13-22) \mathrm{c}$ \\
\hline Pre-oviposition & $4.1 \pm 0.3(3-5) \mathrm{a}$ & $9.3 \pm 1.0(6-15) \mathrm{b}$ & $6.4 \pm 0.4(5-8) \mathrm{a}$ & $9.0 \pm 1.1(6-15) \mathrm{b}$ \\
\hline Oviposition & $41.7 \pm 2.0(13-54) \mathrm{a}$ & $30.8 \pm 1.1(27-36) \mathrm{a}$ & $22.6 \pm 4.2(11-52) \mathrm{b}$ & $18.1 \pm 2.0(11-32) \mathrm{b}$ \\
\hline Fecundity & $80.3 \pm 1.1(15-136) \mathrm{a}$ & $76.1 \pm 13.8(4-147) \mathrm{a}$ & $79.6 \pm 8.4(39-113) \mathrm{a}$ & $65.6 \pm 10.5(20-24) \mathrm{a}$ \\
\hline Egg incubation & $4.6 \pm 0.15(4-5) \mathrm{a}$ & $4.3 \pm 0.15(4-5) \mathrm{a}$ & $4.6 \pm 0.2(4-5) \mathrm{a}$ & $4.7 \pm 0.3(4-6) \mathrm{a}$ \\
\hline
\end{tabular}

Each value is a mean of 10 replicates.

Means followed by the same letter in a row are not significantly different at the 5\% level using DMRT.

The numbers in parentheses are ranges.

The females of A. armigera were oviparous and laid eggs in captivity under laboratory conditions. Eggs were laid indiscriminately in batches of 2 to 40 on the panicles. A few clutches of eggs were also found on the grains. Although there were numerical differences in fecundity, they were not statistically significant. Virgin females laid relatively fewer eggs than their mated counterparts, and they were not viable. The eggs incubated for 4 to 6 days before the nymphs hatched. The mean oviposition periods were shorter on ITA 307 and ITA 315 (41.7 and 30.8 days respectively) than on ITA 301 and ITA 305 (22.6 and 18.1 days respectively) (Table 4$)$.

\section{Morphometrics of developmental stages of Aspavia armigera}

Description of the eggs: Eggs were oval in shape, dirty-white when freshly laid, changing to dark brown at the end of the incubation period. They were taped anteriorly with whitish hair-like projections, the sides surrounded with dark reticulations in two regions; reticulations were also present on the caps of the eggs though not covering the entire surface. The eggs had a mean length of $0.92 \mathrm{~mm}$ and were $0.75 \mathrm{~mm}$ wide, the chorion was transparent with the reticulations only at the sides, and the average incubation period was 4.6 (range $=4$ to 6 ) days.

First to third instar: The body of the first instar was dark-brown in the anterior region and light brown at the abdomen, which was rounded. The head capsule had a pair of compound eyes, two antennae that were not as long as the body, four antennal segments each demarcated by a white band at the joints, and eight abdominal segments with dark brown markings on the edges of each of the last six segments. The mean body length was $1.11 \mathrm{~mm}$, the abdominal width was $0.90 \mathrm{~mm}$ and the vertex width was $0.40 \mathrm{~mm}$. There was a progressive growth to the second instar with the body gradually turning uniformly darkbrown and a growth ratio of 1.35 . The third instar was greenish when freshly moulted but 
turned brownish with time. The prothoracic spines first appeared at this stage, and the growth ratio increased to 1.43 .

Fourth and fifth instars: Body length, width of abdomen and head capsule (vertex) increased progressively in the fourth and fifth instars. The ground colour remained brownish with two prominent yellow spots on the upper part of the scutellum. In the fourth instar, the length of the prothoracic spines increased, and the growth ratio was 1.22. The abdominal segments were more distinct in the fifth instar, giving the appearance of a miniature adult; the growth ratio was 1.27. There was a linear relationship and a significant correlation between nymphal development and head capsule width $(y=0.2+$ $0.17 X ; r=0.99)$.

Adults: Adult were about 6 to $8 \mathrm{~mm}$ long and 4 to $5 \mathrm{~mm}$ wide. The ground colour was brownish with three yellow spots at the apices of the scutellum and a prothoracic spine on either side of its dorsal surface.

Experiment 2: Biology of Aspavia armigera on its alternative hosts: soybean, cowpea, Amaranthus cruentus and rice

Survival and development of nymphal Aspavia armigera on its alternative hosts

The mean incubation periods were 4.6 (4 to 6) days, 4.9 (4 to 7 ) days, (4 to 5) days and 4.8 (4 to 6) days on soybean, cowpea, amaranthus and rice respectively. A. armigera completed its development on the three alternative hosts. The first instar nymphs had the shortest period on cowpea (av. 2.4 (2 to 4) days while fifth instar nymphs had the longest mean developmental period of 8.8 (6 to 11) days on amaranthus. The total mean developmental periods were $25.7,25.5,21.4$ and 20.3 days on soybean, amaranthus, rice and cowpea respectively. Nymphal development was significantly $(\mathrm{p}<0.05)$ delayed on soybean (25.7 days) and amaranthus (25.5 days) (Table 5).

Percentage survival rates of nymphs reared on the alternative hosts were generally high though not significantly different from one another. The highest survival rate was $90.0 \%$ on rice and cowpea, the lowest on amaranthus (82\%). The highest growth index was obtained on cowpea, while the lowest (3.42) was recorded on soybean. The average sex ratio (m:f) was 1: 1.2 (Table 5).

\section{Longevity of mated and unmated adults of Aspavia armigera fed on soybean, cowpea, amaranthus and rice}

The average longevity of mated males of A. armigera fed on soybean, amaranthus, rice and cowpea was 32.1, 29.8, 27.8 and 26.0 days respectively. Unmated males lived for an average of 41 (31 to 60) days on soybean, which was statistically different from the period on amaranthus (37 days), rice (30.4 days) and cowpea ( 8 days). Mated females lived for a significantly shorter period on cowpea (21.9 days) and rice (26 days) (Table 6). 
Table 5. Egg incubation period, mean nymphal development (days \pm S.E), survival, growth index and sex ratio of Aspavia armigera on its alternative hosts.

\begin{tabular}{|c|c|c|c|c|}
\hline \multirow[t]{2}{*}{ Parameter } & \multicolumn{4}{|c|}{ Alternative hists } \\
\hline & $\begin{array}{c}\text { Soybean } \\
(\mathrm{TGX} 1448-2 \mathrm{E})\end{array}$ & $\begin{array}{c}\text { Rice } \\
\text { (ITA 315) }\end{array}$ & $\begin{array}{l}\text { Amaranthus } \\
\text { (NH 84/493) }\end{array}$ & $\begin{array}{c}\text { Cowpea } \\
(\text { IT86D-715) }\end{array}$ \\
\hline Egg incubation & $\begin{array}{c}4.6 \pm 0.22 \\
(4-6)\end{array}$ & $\begin{array}{c}4.8 \pm 0.25 \\
(4-6)\end{array}$ & $\begin{array}{c}4.6 \pm 0.16 \\
(4-5)\end{array}$ & $\begin{array}{c}4.9 \pm 0.35 \\
(4-7)\end{array}$ \\
\hline Instar I & $\begin{array}{c}3.5 \pm 0.17) \\
(3-4)\end{array}$ & $\begin{array}{c}3.2 \pm 0.13 \\
(3-4)\end{array}$ & $\begin{array}{c}3.3 \pm 0.15 \\
(3.4) \\
\end{array}$ & $\begin{array}{c}2.4 \pm 0.22 \\
(2-4)\end{array}$ \\
\hline Instar II & $\begin{array}{c}4.0 \pm 0.25 \\
(3-5)\end{array}$ & $\begin{array}{c}3.1 \pm 0.1 \\
(3-4)\end{array}$ & $\begin{array}{c}3.7 \pm 0.26 \\
(3-5)\end{array}$ & $\begin{array}{c}2.9 \pm 0.23 \\
(2-9)\end{array}$ \\
\hline Instar III & $\begin{array}{c}4.9 \pm 0.2 \\
(4-6) \\
\end{array}$ & $\begin{array}{c}3.7 \pm 0.21 \\
(3-5) \\
\end{array}$ & $\begin{array}{c}4.7 \pm 0.26 \\
(4-6) \\
\end{array}$ & $\begin{array}{c}3.7 \pm 0.15 \\
(2-9) \\
\end{array}$ \\
\hline Instar IV & $\begin{array}{c}4.8 \pm 0.25 \\
(4-6)\end{array}$ & $\begin{array}{c}4.4 \pm 0.22 \\
(3-5)\end{array}$ & $\begin{array}{c}5.0 \pm 0.26 \\
(4-6)\end{array}$ & $\begin{array}{c}4.4 \pm 0.27 \\
(8-5)\end{array}$ \\
\hline Instar V & $\begin{array}{c}8.5 \pm 0.76 \\
(6-12) \\
\end{array}$ & $\begin{array}{c}7.0 \pm 0.15 \\
(6-8) \\
\end{array}$ & $\begin{array}{c}8.8 \pm 0.47 \\
(6-11) \\
\end{array}$ & $\begin{array}{c}6.9 \pm 0.23 \\
(5-8) \\
\end{array}$ \\
\hline Mean developmental period & $\begin{array}{c}25.7 \pm 0.97 \mathrm{a} \\
(21-32)\end{array}$ & $\begin{array}{c}21.4 \pm 0.43 \mathrm{~b} \\
(18-23)\end{array}$ & $\begin{array}{c}25.5 \pm 1.5 \mathrm{a} \\
(23-29)\end{array}$ & $\begin{array}{c}20.3 \pm 0.45 \mathrm{c} \\
(18-22)\end{array}$ \\
\hline Mean survival (\%) & $88.0 \mathrm{a}$ & $90.0 \mathrm{a}$ & $82.0 \mathrm{a}$ & $90.0 \mathrm{a}$ \\
\hline Growth index & 3.42 & 3.52 & 3.83 & 4.43 \\
\hline Sex ratio & $1: 1.4$ & $1: 1.12$ & $1: 1.10$ & $1: 1.2$ \\
\hline
\end{tabular}

Means followed by the same letter in a row are not significantly different at the 5\% level using DMRT. The numbers in parentheses are ranges.

Table 6. Mean longevity (days \pm S.E.) of adult of Aspavia armigera reared on its alternative hosts.

\begin{tabular}{lcccc}
\hline \multirow{2}{*}{ Alternative hosts } & \multicolumn{4}{c}{ Male longevity \{days) } \\
\cline { 2 - 5 } & \multicolumn{3}{c}{ Male } & \multicolumn{2}{c}{ Female } \\
\cline { 2 - 5 } & Unmated & Mated & Unmated & Mated \\
\hline Soybean & $41.0 \pm 2.45 \mathrm{a}$ & $32.10 \pm 1.17 \mathrm{a}$ & $38.30 \pm 2.71 \mathrm{a}$ & $30.1 \pm 2.21 \mathrm{a}$ \\
(TGX 1448-2E) & $(31-60)$ & $(27-49)$ & $(24-49)$ & $(21-46)$ \\
\hline Rice & $30.0 \pm 2.0$ & $16.0 \pm 1.6$ & $17.6 \pm 1.9$ & $12.3 \pm 1.6$ \\
(ITA 315) & $(6-23)$ & $(7-29)$ & $(9-23)$ & $(6-21)$ \\
\hline Amaranthus & $37.0 \pm 4.4 \mathrm{~b}$ & $29.8 \pm 3.9 \mathrm{a}$ & $40.8 \pm 4.2 \mathrm{a}$ & $27.5 \pm 31.7 \mathrm{ab}$ \\
(NH84/93) & $(7-51)$ & $(12-40)$ & $(15-61)$ & $(10-51)$ \\
\hline Cowpea & $28.4 \pm 4.9 \mathrm{~b}$ & $26.0 \pm 2.75 \mathrm{a}$ & $34.5 \pm 3.0 \mathrm{a}$ & $21.9 \pm 3.67 \mathrm{~b}$ \\
(IT86D-715) & $(6-44)$ & $(21-55)$ & $(21-50)$ & $(10-51)$ \\
\hline
\end{tabular}

Means followed by the same letter in a row are not significantly different at the 5\% level using DMRT. The numbers in parentheses are ranges. 
Pre-mating, mating, pre-oviposition, oviposition periods and fecundity of Aspavia armigera on its alternative hosts

The mean pre-mating period of $A$. armigera was 8.4 days on soybean, 15.1 days on cowpea, 10.7 days on amaranthus and 10.5 days on rice (Table 7). The pre-oviposition period of a mated female was 13.0 days on soybean, 16.0 days on cowpea, 17.6 days on amaranthus and 12.3 days on rice. Oviposition periods recorded for A. armigera on its alternative hosts ranged between 5 and 20 days on cowpea and 6 and 18 days on rice (control). Significantly higher numbers of eggs (fecundity) were laid by mated females of A. armigera fed on soybean than those fed on cowpea. The fecundity of mated females on amaranthus was not significantly different from that on rice (Table 7).

Table 7. Premating, pre-oviposition, oviposition periods (days \pm S.E) and fecundity of Aspavia armigera on its alternative hosts.

\begin{tabular}{lcccc}
\hline \multirow{2}{*}{ Period (dasys) } & \multicolumn{4}{c}{ Alternative hists } \\
\cline { 2 - 5 } & $\begin{array}{c}\text { Soybean } \\
\text { (TGX 1448-2E) }\end{array}$ & $\begin{array}{c}\text { Cowpea } \\
\text { (IT86D-715) }\end{array}$ & $\begin{array}{c}\text { Amaranthus } \\
\text { (NH493) H84/ }\end{array}$ & $\begin{array}{c}\text { Rice } \\
\text { (ITA 315) }\end{array}$ \\
\hline \multirow{2}{*}{ Pre-mating } & $8.4 \pm 1.3$ & $15.1 \pm 1.7$ & $10.7 \pm 1.7$ & $10.5 \pm 1.6$ \\
& $(5-16)$ & $(6-25)$ & $(6-25)$ & $19)$ \\
\hline \multirow{2}{*}{ Pre-oviposition } & $13.0 \pm 2.0$ & $16.0 \pm 1.6$ & $17.6 \pm 1.9$ & $(9-23)$ \\
\hline \multirow{2}{*}{ Oviposition } & $(6-23)$ & $(7-29)$ & $13.4 \pm 1.2$ & $(6-21)$ \\
\hline \multirow{2}{*}{ Fecundity } & $10.8 \pm 1.3$ & $10.3 \pm 1.7$ & $(6-18)$ & $13.8 \pm 1.2$ \\
& $(5-16)$ & $(5-20)$ & $21.4 \pm 2.7 \mathrm{ab}$ & $23.1 \pm 3.1 \mathrm{ab}$ \\
\end{tabular}

Means followed by the same letter in a row are not significantly different at the 5\% level using DMRT. The numbers in parentheses are ranges.

\section{DISCUSSION}

This study has shown that the development of nymphs of A. armigera was successfully completed on the four rice varieties (ITA 301, ITA 305, ITA 307 and ITA 315). This suggests that these varieties supported the population growth of A. armigera in the field. The long oviposition period and high fecundity of mated females when fed on soft panicles of ITA 301 and the corresponding shortest developmental period are pointers to the fact that this variety is the most suitable of the four varieties tested. This also implies that rice fields planted with ITA 301 will aid population explosions of A. armigera within a short period. Although differences in A. armigera fecundity among the rice varieties were not significant, the relatively low number of eggs laid by mated females on ITA 315 and the delayed development of $A$. armigera on this variety suggest some level of antibiosis. This 
type of resistance was among the three types of resistance described by PAINTER (1951). These observations agree with similar work conducted in Ibadan by OLAGBAJU (1988) and EWETE \& OlagbaJU (1990) on cowpea and different rice varieties, where cowpea TVu1890 was found to exhibit antibiosis.

According to SAUPHANOR (1985) and SLANSKY \& PANIZZI (1987), the suitability of different crop varieties for insect reproduction, development and growth may be determined by the amount of anti-growth substances such as allelochemicals. Growth inhibitors have been confirmed in legumes which form the basis of resistance or otherwise of crops to insect attack (PAINTER 1951, KogAn 1975, AKInSOla 1979, Weder 1981, DobIE 1984). Thus, the presence of these chemical substances, suspected in seeds of ITA 315, may have been responsible for the significantly low mean survival as well as the low growth index recorded on this variety. However, the high mean percentage survival of this bug on ITA 301 also supports its suitability. Similar work on host suitability with the rice feeding tiger moth Crantonotus gangis L. was reported by CATINDIG (1993). The significant shorter life span of mated females of A. armigera on ITA 315 suggests that this variety cannot support its population increase. Similar results on the life span of A. armigera on other crops such as cowpea and soybean have been reported (EGWUATU \& TAYLOR 1977, SCHALK \& FERY 1982, АКОв 1990).

The increasing sizes of the head capsules of the immature stages of A. armigera confirmed earlier reports that there are five nymphal instars in A. armigera (AINA 1975, OCHIENG 1977, EWETE \& OlaGBAJU 1990). Similarly, the mean growth ratio of 1.32 obtained in this study was close to the value 1.4 postulated by DYAR (1890) for lepidopteran larvae, indicating that the growth of A. armigera progressed at a constant rate at each moult (DYAR 1890, Richards 1949, MBUYONGA 1991, ODEBIYI 1981, OlaGBAJU 1988).

The nymphal development of this bug on soybean, cowpea and amaranthus was completed successfully, indicating that these other crops also supported its population growth. However, the long developmental period on amaranthus showed that this crop is less favourable to the bug's development. Nevertheless, the high percentage nymphal survival, as well as the highest growth index recorded by this bug on cowpea, indicates that this contains less of the growth inhibitors mentioned by WEDER (1981), and is therefore the most preferred by the bug. The shortest nymphal developmental period, the high percentage survival and highest growth index of A. armigera on cowpea pods also suggest that this crop will support a rapid population build-up of this pest. The developmental period may be longer and the mortality rate higher under natural conditions because of several environmental factors that come into play. Generally, the features revealed in this lifecycle study point to the short developmental period of A. armigera and its ability to colonize its 
host and reproduce at a fast rate. This makes A. armigera an economic pest which is deserving of immediate attention.

\section{REFERENCES}

AINA J.O. 1975. The life history of Riptortus dentipes F. (Hemiptera: Alydidae). A pest of growing cowpea pods. Journal of Natural History, 9 (5): 589-596.

AKINSOLA E.A. 1979. Insect pests of rice in Africa III: Minor and potential pests. A lecture handout prepared for Rice Production Training for Research Workers and Extension supervisors in Tropical Africa. September 7-December 11, 1981, IITA, Ibadan, Nigeria.

Аков C.A. 1990. The development and pest status of Aspavia armigera FABRICIUS (Hemiptera: Pentatomidae) on soybean. M.Sc. Thesis, University of Ibadan, Ibadan.

Alam M.S., Gibbons J., AKibo-BetTs D., Wasano K., Efron Y. 1983. Hopper burn in rice caused by brown hopper. IITA Research Briefs, 4 (1,2,3): 6-7.

BurdeOH A.T., GABRIEL B.P. 1995. Virulence of different Metarhizium anisopliae (METSCH.) Sorokin isolates against the rice bug, Leptocorisa oratorius FABR. The Philippine Entomologist, 9 (5): 467-478.

CAtindig J. L.A., BARRion A.T., Litsinger J.A. 1993. Developmental biology and host plant range of rice feeding tiger moth, Creatonotus gangisi L. International Rice Research Newsletter, 18 (3): $34-35$.

DOBIE P. 1984. Biological methods for integrated control of insects and mites in tropical stored products. 1. The use of resistant varieties. Tropical Stored Products Information, 48: 4-7.

DyAR H.G. 1890. The number of molts of Lepidopterous larvae. Psyche, 5 (175-175): 420-422.

Egwuatu R.I., TAylor T.A. 1977. Studies on the biology of Acanthomia tomentosicollis (STÅL) (Hemiptera: Coreidae) in the field and insectary. Bulletin of Entomological Research, 67 (2): 249-257.

Ewete F.K. Olagbaju R.A. 1990. The development of Aspavia armigera Fabricius (Hemiptera: Pentatomidae) and its status as a pest of cowpea and rice. Insect Science and its Application, 11 (2): 171-177.

Foster R.E., CHERRY R.H., JONES D.B. 1989. Spatial Distribution of the Rice Stink Bug (Heteroptera: Pentatomidae) in Florida Rice. Journal of Economic Entomology, 82 (2): 507-509.

IITA [International Institute of Tropical Agriculture] 1984. International Production Training Manual Vol. 2. Chapters 9-18. Manual series No. 13. IITA, Ibadan.

John V.T., Alam M.S., ThotTappilly G. 1986. Diseases and insect pests of wetland rice in tropical Africa. [in:] A.S.R. JUA, J.A. LIKEL (eds.). The wetland and rice in sub-Sahara Africa. Proceeding of an International Conference in Wetland Utilization for Rice Production sub-Sahara Africa, 4-8 November, 1985. IITA, Ibadan: 141-150.

Joda A.O., Ewete F.K., Singh B.N., PITAN O.R. 2015. Varietal Differences in Rice (Oryza sativa L.) Resistance to the Shield Bug, Aspavia armigera (FABRICIUS) (Hemiptera: Pentatomidae)\. Journal of Agricultural Science, 7 (5): 211-218. 
Kogan J. 1975. Chemical composition of soyabean. [in:] J.A. Harlan (ed.). Crops and man. Agronomy Society of America Madison, Wisconsin, 34-54

Litsinger J.A., BARRion A.T., Soekarna D. 1986. Upland rice insect pests: their ecology, importance and control. [in:] Progress in Upland Rice Research. Proceedings of the 1985 Jakarta Conference. IRRI, Manila, Philippnes, 403-445.

MbuYonga B.V. 1991. The development and relative abundance Aspavia armigera F. (Hemiptera: Pentatomidae) on soybean, rice and amaranthus M.Sc. Thsesis, University of Ibadan, Ibadan.

OCHIENG R.S. 1977. Studies on the bionomics of two major pests of cowpea (Vigna unguiculata L. WALP.), Ootheca mutabilis SAHL. (Coleoptera: Chrysomelidae) and Anoplocnemis curvipes (F.) (Hemiptera: Coreidae). Ph.D. Thesis, University of Ibadan, Ibadan.

ODEBIYI J.A. 1981. Studies on the Biology of the Cowpea Pod-Borer, Maruca Testulalis in Kenya - I. Determination of the Larval Instars. Insect Science and Its Application, 1: 339-441.

Olagbaju R.A. 1988. Studies on the bionomics and population assessment of Aspavia armigera on cowpea and rice. M.Sc. Thesis, University of Ibadan, Ibadan.

PAINTER R.H. 1951. Insect resistance in crop plants. The Macmillan Company, New York.

Pitan O.O.R., OdubiYi S.I.I., Olatunde G.O. 2007. Yield response of cowpea, Vigna unguiculata L. (WALP.) to infestation of Aspavia armigera F. (Hemiptera: Pentatomidae). Journal of Applied Entomology, 131 (9-10): 704-708.

RICHARDS O.W. 1949. The relation between measurements of the successive instars of insects. Proceedings of the Royal Entomological Society of London (A), 24 (1-3): 8-10.

SAUPHANOR B. 1985. Some Factors of Upland Rice Tolerance to Stem-Borers in West Afric. Insect Science and its Application, 6 (3): 429-434.

SchalK J.M., Fery R.L. 1982. Southern Green Leaf-Footed Bug and Leaffooted BuG: Effect on Cowpea Production. Journal of Economic Entomology, 75 (1): 72-75.

Slansky F. Jr., PANIZZI A.R. 1987. Nutritional ecology of seed-sucking insect. [in:] F. SLANSKY, J.G. RODRIGUEZ (eds.). Nutritional ecology of insects, mites, spiders and related invertebrates. John Wiley and Sons, New York, 283-320.

UmeH E.D.N., Joshi R.C., UkwUngwU M.N. 1991. Field insect pests of rice in Africa: Biology and control. [in:] IITA Research guide No. 43. IITA Ibadan, Nigeria, 7-11.

WedER J.K.P 1981. Protease inhibitors in the Leguminosae. [in:] R.M. Polhill, P.H. RAVEN (eds.). Advances in legume systematic, part 2. (Proc Int Legume Conf, Kew, 24-29 July 1978, vol 2). Royal Botanic Gardens, Kew, 533-560.

Received: 24 October 2018

Accepted: 16 August 2019 